\title{
Study on the Integration of Life education and Ideological and Political Education in Colleges and Universities
}

\author{
Zhao Xin \\ School of Marxism, Qilu Normal University, Jinan 250200, China
}

Keywords: Life education; Ideological and political education; Integration

\begin{abstract}
The study on life education has grown up over recent years, the integration of life education and the ideological and political education contributes to improving the effectiveness and appeal of ideological and political education in colleges and universities, keeping up with the development of the times, and helping students build a correct view on the world, life and values.
\end{abstract}

\section{Related research on life education}

\subsection{Foreign studies on life education}

The practice of life education in western countries has been carried out earlier around the world, but each country has a particular theme. Jay Donald Walters, an American, founded Ananda school in 1960s, began to advocate and practice life education theories which has been popularized hereafter in the United States. Related courses were set up in primary and secondary schools, thus life education theories has basically been popularized in 1990s; in 1979, Australia founded "the research center of life education", whose major goal was to prevent "drug abuse, violence and AIDS"; in 1989, for the act of students' suicide, murder, waste, destruction of the environment and other practical issues, Japanese clearly stated that the goal of moral education was set on the basis of the respect for people and the reverence for life, and the teaching syllabus was revised; in 1986, the British established the first mobile classroom to carry out life education, then the mobile classroom, which played an important role in reducing the harm of drugs, became popularized,.

\subsection{Domestic research on life education}

"Life education" began to appear in China in the middle and late 1990s, and it was carried out more lately in colleges and universities. In 2002, Wuhan University began to conduct life education to students, organized a large-scale lecture entitled "the wisdom of life, how to be kind to and develop your life that you only live once; in 2004, Tsinghua University carried out outdoor activities in life education; in 2005, Fudan University offered the selective course of "life education"; in 2008, mental health and life education center in Zhejiang University of Media and Communications was established, as well as the first specialized "Life Science and Life Education Research Institute"; in 2008, "Sansheng Education" in all kinds of schools was promoted in Yunnan province, which means life education, live education, survival education, and a series of textbooks were written, and then used by all kinds of school, causing strong wave in the country, to a certain extent, promoted the popularization of life education; in 2010, initiated by the professor, Xiao Chuan, the life education research center of Beijing Normal University was established to promote the systematic research and practical exploration of life education throughout the country.

\section{The present situation of the integration of ideological and political education and life education}

Quality-oriented education has been carried out in our country since 1990s, thus the original educational concept which takes knowledge and scores as a measure standard was changed. Quality-oriented education should be carried out in an all-round way, and we should understand the essence and purpose of education from the perspective of human nature, as well as respect, care for 
and understand everyone. In 2002, Wuhan University organized a lecture entitled "the wisdom of life, how to be kind to and develop your life that you only live once”, which has aroused people's attention and concern. In 2004, the Central Committee of the State Council issued "opinions on strengthening and improving the ideological and moral construction of juveniles". The document stressed the need to strengthen life education for juveniles. In the same year, "life education" was stipulated as an important regular course in primary and secondary schools in Liaoning province. In 2005, the Shanghai Municipal Education Commission and the Science and Education Committee jointly issued "The Outline of Life Education in Primary and Secondary Schools in Shanghai (Trial Implementation)", and carried out life education for primary and secondary school students throughout the whole city. The research on life education for university students started in 2007. On the first session of the "Summit Forum on life education for college students", the experts and scholars from Wuhan University, Beijing Normal University, Jiangxi Normal University and other universities gathered to discuss and publish "Life Education for University students' reading" chiefly edited by Professor Gu Hailiang. Currently the activities of life education in many colleges and universities is held on the basis of the center of mental health education, the importance of life education in moral education guidance institutions set up by the government, in Shandong Province, Provincial University Committee has always attached great importance to the work of university students' life education. In June 2016, "Notification on 'The Outline of Integrated Reform of Moral Education in Universities in Shandong Province (Trial Implementation)'” was issued (Provincial University Committee [2016] No. 58), the content of moral education contains "to carry out life education, psychological health education, personality and psychological education, and the education of the ways of psychological adaption.”

Overall, how to integrate life education into the ideological and political education within university students, the ideological education is the main body, sharing and experience teaching should be implemented, so as to further explore the integration of all resources from school, family to society, and for a long time, the ideological and political education featuring appeal and effectiveness among university students is an important subject that we have to face.

\section{The necessity of the integration of life education and ideological and political education in universities}

\subsection{Enable the ideological and political education to better serve the education of university students}

At any time, education is always starting from the people, promoting the progress and development of human beings, affording people lifelong benefit, and the purpose of education is to cultivate the healthy development of people, so is the goal of ideological and political education, "to cultivate socialist builders and successors of all-round development". With the purpose of improving life value, real education is life-based, following the characteristics of life. Education should guide people to pursue the meaning of life, pursue the perfection of life, for a long time, the ideological and political educators lack the idea of life education, and ignore the compatibility and correspondence between these two forms of education, even separate the two, resulting in a lack of ideological and political education, thus good results and the goal of value is hardly received, for life education, people should pay attention to individual life, cherish and love life, realize the value of life, which is consistent with the goal of the ideological and political education, namely, to achieve people's all-round development. Therefore, integrating life education into the ideological and political education in universities, learning from the theory and practice of life education, promoting the innovation and development of Ideological and political education, restoring the charm and appeal of the ideological and political education, setting up the correct outlook on life and the values, enabling students to keep clear the meaning and direction in life during university, all the above are the significance of university education. 


\subsection{Enrich the content of ideological and political education in universities}

Life education is a part of the ideological and political education system. Currently the ideological and political education in university is to help students establish a correct outlook on the world, life, values, moral values, love, friendship, the content involved is quite rich, while the content of education of life and death is relatively less, lacking deep excavation of the meaning of life. To carry out the education of university students' outlook on life is to enable students to face life, think about life, and correct the attitude of life, and to encourage students to think about the meaning of life by their understanding of life, being kind to life and their love for life, which can contribute to forming right outlook on life and value. Life education enriches the content of ideological and political education, making it more plump and convincing. In life education, the education of reverence and being king to life, the education of healthy life style, the education of the idea of life and death, mental health education, disaster education, death education, frustration education, life experience education and gratitude education, and other forms of education further enrich the content of ideological and political education, enhance the effect of ideological and political education.

\subsection{Promote the integration of life education and ideological and political education in universities}

There are many similarities in life education and ideological and political education: the concept and essence of education is consistent; and the content is intermingled with each other. The ideological and political education, with the development of human thought and morality as its purpose, is spiritual activities. The important goal is to cultivate and promote people's consciousness of caring for life. Caring for life means not only the concern for the individual's natural life, but more importantly the value of life and the guidance of the attitude of life. With respecting life and personal dignity as the starting point, ideological and political education respects the regularity and various forms that people display in their life activities, and utilize life resources to maintain peoples' morality and cultivation, so as to improve the quality of human life and realize the value of human life. Life education advocates that education must return to the individual life itself, take the individual life as the logical starting point, and take the road of life and humanization. The ideological and political education of university students can integrate into the concept of life education, improve the teaching goal of ideological and political theory, the integration of ideological and political education is set to train and improve the ideological and political quality of the educated.

\subsection{The necessity of the integration of ideological and political education and students' life education in colleges and universities}

On the one hand, the ideological and political education in universities undertakes the important task of training students' outlook on life and values. With the further development of political pluralism and economic globalization, the competition between science, technology and talents is becoming increasingly fierce, hence the ideological and political education in universities faces more new challenges. For a long time, teachers and students are accustomed to the class of “teachers' speaking” and "students' learning”, and the teaching process is only within the dozens of minutes, the practice of class theory is insufficient. In addition, in the process of ideological and political education, the macro level of the national society is overemphasized, the close connection with students' actual thoughts is absent. Thus the anticipated effect of the ideological and political education universities cannot be achieved. Launching life view education course, enriching the content of ideological and political education, and offering life view education course in schools, can better improve the effect of ideological and political education and make its more perfect. Introducing the concept of caring for life in the idea of ideological and political education, integrating Chinese and foreign excellent views of life into educational contents, building a reasonable educational mechanism including family, school and society, and establishing a diversified evaluation system of scientific education, all these can enable ideological and political 
education to get rid of the current predicament.

\section{The ways and measures of the integration of ideological and political education and life education in universities}

\subsection{To integrate the education of life concept into the ideological and political theory course in universities}

Ideological and political theory course is the main position and carrier of ideological and political education in universities. Generally speaking, for ideological and political education, the political and ideological theories are instilled into students' minds in class. For a long time, teachers and students are accustomed to the class of "teachers' speaking" and "students' learning". In political and ideological education, it is difficult to transform values and goals of politics and ideology to students' own values, let alone applying this concept in real life. Therefore, it is necessary to infiltrate life education in the ideological and political theory course. The value of ideological and political education is reflected by the activities of life. To cherish life and love life is a basic value. To carry out the education of students' outlook on life is to enable students to face life, think about life, and correct the attitude of life, and to encourage students to think about the meaning of life by their understanding of life, being kind to life and their love for life, which can contribute to forming right outlook on life and value. To integrate life education into ideological and political theory course can enable our ideological and political education to connect with the soul, make it more warm and caring, and to enhance the appeal, attraction, and also the teaching effect of ideological and political theory course.

\subsection{To combine the content of life education with the practical course of ideological and political theory}

The practical course of ideological and political theory has developed rapidly in recent years, thus the practical teaching system and teaching mode has gradually formed. Relevant departments have paid more and more attention and investment to practical teaching. Practical teaching resources are becoming increasingly rich. The practice of life education combines the practical course of ideological and political theory, such as frustration education, gratitude education, the education of mental health of love and other kinds of education. Through infiltrating the practical course of ideological and political theory in the concept and idea of life education, the objective of life education can be achieved, and the teaching content of ideological and political theory course can also be improved through better understanding and consolidation.

\subsection{Ways in integrating resources and expanding the ideological and political education in universities with life education as the carrier}

The content of life outlook education involves a wide range of aspects, and schools are combined with family and society. Besides launching the life education curriculum, we carry out various extracurricular activities such as thematic education, social activities and community activities, so as to make school, families and society participate together, and to form join forces. The social recognition, attention and support of life outlook education, and the formation of good educational atmosphere will inevitably form join forces of ideological and political education, and optimize the environment of ideological and political education. We should gradually integrate life education as a carrier into ideological and political education in many aspects such as school education, family education and social education, and jointly build a strong fortress for students' healthy growth. Therefore, life education provides a new perspective and opens up a new path for the ideological and political education of today's university students.

\section{Acknowledgements}

Project Name: the study of life into the ideological and Political Education - take the universities of Shandong Province as an example; project number: J16YB53 


\section{References}

[1] Li Fang, Liu Dan, "Study on Life Education and Ideological and Political Education of University Students”, “Journal of the Education of Ideological Theory”, 2011-10-20.

[2] Han Fengxia, “An analysis of University Students' Life Education in the Perspective of Ideological and Political Education”, “Journal of Social Science in Jiamusi University”, 2014-08-15.

[3] Hu Mo, He Tianyuan, "The Outline of University Students' Life Education in the Perspective of Ideilogical and Political Education”, “Social Sciences Review”, 2016-07-15.

[4] Yang Yan, Chao Chuanxuan, "Life Education: The Basic Point of University Students' Ideological and Political Education”, “Education and Occupation”, 2014-0-11.

[5] Liu Yan, "On the Effective Integration of Life Education and Ideological and Political Education of University Students”, “Modern Communication”, 2014-11-15.

[6] Zhu Meng, “The Education of University Students’ Life Values in the Perspective of Ideological and Political Education: Connotations, Characters and Functions", "Theory and Reform”, 2015-03-15.

[7] Zhang Liye, “Study on Life Education in the Perspective of University Students' Ideological and Political Education”, “China Chizi” (midmonth), 2014-09-15.

[8] Zhu Yuhang, “The Lack of University Students' Life Education and the Corresponding Countermeasure in the Perspective of Ideological and Political Education”, “Journal of Guangdong University of Foreign Studies”, 2013-03-30.

[9] Han Hua, "The Ideological and Political Education of University Students in the Perspective of Humanistic Concern”, “Journal of Ideological and Theoretical Education”, 2009-02-20.

[10] Li Xiaoling, "The Problem of Life Education in the Ideological and Political Education of University Student”, “Social Science in Hubei”, 2015-03-04. 